\title{
Climate Refugee and Disappearing States: In Need for a New Legal Regime?
}

\author{
Jerry I-H Hsiao \\ University of Macau, Macau, China
}

\begin{abstract}
Climate change brings unprecedented challenges to both the international community as well as international law. For example, extreme weather conditions might cause States to disappear and force its populations to migrate. These phenomenon creates new challenges for current international law. First, under current legal frameworks, there is no provision regarding the disappearance of a State due to climate change. Second, for people who are forced to migrate due to climate change whether caused internally or internationally, current legal framework is also unclear to whether they could be classified as refugees and to what extent should they be protected. Despite these uncertainties, people of these endangered States cannot be left to fend themselves simply because there is a legal vacuum. This paper proposes a way forward for to meet this challenge and urge the international community to use this opportunity to refine the currently existing legal regime in order to solve the various challenges posed by climate change.
\end{abstract}

Keywords: climate refugee, small-island states, sea-level rise, artificial islands, international law

\section{Introduction}

Climate change has been identified as the "defining human development issue of our generation" (U.N. Development Programme, 2007) and "biggest humanitarian and economic challenge that the developing world will have to face in the coming decade" (Rajan, 2008). While climate change was once considered an environmental issue, it is now widely recognized to include issues such as health, migration, employment, and ultimately, international peace and security (Atapattu, 2009). Climate changes brings different consequences and among them is rising sea-level. This is a serious concern for the East Asian countries, for example, Bangkok and Tokyo are both large populous cities that might be affected by the rising sea levels. This issue is more urgent for South Asian countries like Maldives.

The main processes contributing to sea level rise include the expansion of ocean water as temperatures increase, ice caps and glaciers melting, and Antarctica losing their ice masses (Thead, 2016). Climate change poses unprecedented challenges for the international community and international law (Atsapattu, 2014). However, twenty years after the Kyoto Protocol and there is still a lack of urgency for the international community to accomplish anything substantive (Koenig, 2015). Globally, ocean levels rose 19 centimeters over the last century, and the rate has increased; over the past twenty years the rate doubled to 3.2 millimeters per year over the 20th century, an average of 1.7 millimeters per year (Jones, 2013).

Over the past twenty years, there have been some major international agreements, the United Nations

Jerry I-H Hsiao, Ph.D., Assistant Professor, Faculty of Law (FLL), University of Macau. 
Framework Convention on Climate Change (UNFCCC), the Kyoto Protocol, the framework adopted at the U.N. Climate Change Conference in Bali, the 2009 Copenhagen Accord (Barbour, 2010) and most significantly, the Paris Agreement of 2016. ${ }^{1}$ While each is a laudable attempt to address climate change, each attempt was marked by problems and setbacks. This is not surprising, because of the complex issues surrounding climate change. $^{2}$ There are differences in opinion between developed and developing countries, coastal and landlocked countries, and major and minor greenhouse gas emitters. It is no secret that some states or communities will experience more adverse effects than the others such as low-lying cities, poor and indigenous communities and specifically Small-Island States. ${ }^{3}$ This paper discusses issues regarding to disappearing states, climate refugee and the challenges for international law.

\section{Climate Change and Issues at Hand}

The Intergovernmental Panel on Climate Change (IPCC) recognized unequivocally in its 4th report that global greenhouse gas emissions due to human activities have contributed to the warming of the Earth's surface (Intergovernmental Panel on Climate Change 4th Report, 2007). In 2007, the IPCC concluded with "very high confidence" that "small islands, whether located in the tropics or higher latitudes, have characteristics which make them especially vulnerable to the effects of climate change, sea-level rise, and extreme events". ${ }^{4}$ The present objective of the international legal framework is mitigation of climate change, this is the aim for both the UNFCCC and the Kyoto Protocol.

The scientific community however, has recognized that mitigation alone is insufficient to combat this issue and strategy of adaptation ${ }^{5}$ is as crucial as mitigation. Despite the fact that the World Commission on Environment and Development (WCED) had the foresight to recognize the need for both mitigation and adaption two decades ago, ${ }^{6}$ the international committee has been slow to act on these recommendations. Given the complexity of the issue and the fact that people rarely migrate solely on environmental reasons, it is hard to find accurate numbers of those displaced due to environmental factors or specifically due to climate change. ${ }^{7}$

International community have to take measures to both mitigate the consequences of climate change and to adapt to its consequences. Under the UNFCCC, developed states has an obligation to assist developing states that are particularly vulnerable to adverse effects of climate change in meeting costs of adaption to those adverse effects. $^{8}$ With regard to displacement and migration caused by climate change, there are displacement

\footnotetext{
${ }^{1}$ The Paris Agreement builds upon the Convention and - for the first time - brings all nations into a common cause to undertake ambitious efforts to combat climate change and adapt to its effects, with enhanced support to assist developing countries to do so. As such, it charts a new course in the global climate effort.

${ }^{2}$ Reed supra 6 at 508

3 Sumudu, supra 3 at 612.

${ }^{4}$ Nobou Mimura et al., Chapter 16. Small Islands, in Climate Change 2007: Impacts, Adaptation and Vulnerability (Martin Parry et al, eds. Cambridge University Press, 2007) 689.

5 Adaptation is defined as “...finding and implementing sound ways of adjusting to climate change...” United Nations Framework Convention on Climate Change, Technologies for Adaptation to Climate Change 4 (2006), available at http://unfccc.int/resource/docs/publications/tech_for_adaptation_06.pdf.

${ }^{6}$ See World Comm'n on Env't and Dev., Our Common Future 291 (1987). A recent document to endorse adaptation is the Bali Action Plan, a product of the United Nations Climate Change Conference in Bali in December 2007. United Nations Climate Change Conference, 3-14 Dec., Nusa Dua, Bali, Indonesia, http://unfccc.int/meetings/cop_13/items/4049.php. The Conference of Parties called upon parties to take enhanced action on Adaptation. Conference of Parties, Bali Action Plan 2 (2007), http://unfccc.int/files/meetings/cop_13/application/pdf/cp_bali_action.pdf (advance unedited version).

7 Sumudu, supra 3 at 610.

${ }^{8}$ United Nations Framework Convention on Climate Change, May 9, 1992, 1771 U.N.T.S. 107, 31 I.L.M. 849, 1220, available at http://unfccc.int/resource/docs/convkp/conveng.pdf. .
} 
caused by the sudden onset of climatic disruption such as the hurricane, and displacement caused the gradual consequences associated with climate change such as rising sea levels. The differences between the two is that displacement related to sudden climatic disruption might be temporary while displacement related to sudden climatic disruption will likely to be permanent. ${ }^{9}$

\section{International Law and Climate Change}

\section{Refugee and Environmentally Displace Persons}

When people migrate across international borders, irrespective of the reason, international law must govern the legal situation created by that movement because the main link between people and their state is nationality. ${ }^{10}$ Under international law principles, the reason why people leave their homes crucial to their rights. For legal purposes, those who cross national borders are referred to as "refugees", while those who flee their homes but remain within boundaries of their own country are referred as "internally displaced people" (IDPs). While international law has sought to regulate the plight of refugees, the international community has yet to adopt a binding instrument on IDPs. ${ }^{11}$

Under the Geneva Convention relation to the Status of Refugees of 1951, refugee is a person who "owing to a well-founded fear of being persecuted for reasons of race, religion, nationality, membership of a particular social group or political opinion, is outside the country of his nationality and is unable, or owing to such fear is unwilling to avail himself of the protection of that country; or who, not having a nationality and being outside the country of his former habitual residence as a result of such events, is unable or, owing to such fear, is unwilling to return to it”. ${ }^{12}$ Under this definition, climate refugee does not satisfy as refugee.

According to the UN Guiding Principle on Internal Displacement, it defines internally displaced persons as "persons or groups of persons who have been forced or obliged to flee or to leave their home or places of habitual residence, in particular as a result of or in order to avoid the effects of armed conflict, situation of generalized violence, violations of human rights or natural or human-made disasters, and who have not crossed an internally recognized State border". ${ }^{13}$ The UN has recognized that environmental factors may trigger displacement and proposed the term "environmentally displace persons" (EDP) to describe those persons "who are displaced from or who feel obligated to leave their usual place of residence, because their lives, livelihood and welfare have been placed at serious risk as a result of adverse, environmental, ecological, or climatic process and event” (Gorlick, n.d.).

The United Nations High Commissioner for Refugees (UNHCR) distinguishes between refugee and EDP, the loss of national protection is a key element of the refugee definition. According to UNHCR using the term environmental refugee to refer to all people forced to leave their homes because of environmental change loses the distinctive need of refugees for protection. It blurs the respective responsibilities of national government towards their citizens and of international community towards who are without protection. For the UNHCR, the

\footnotetext{
9 Sumudu, supra note 3 at 614 .

${ }^{10}$ See David Bederman, International Law Frameworks (New York: Foundation Press, 2006) 73.

11 Sumudu, supra 3 at 616.

12 Convention Relating to the Status of Refugees, July 28, 1951, 189 U.N.T.S. 150.

13 The UN adopted a set of non-binding principles governing IDPs in 1998. See The Secretary-General, Report of the Representative of the Secretary-General, Mr. Francis M. Deng, on the Guiding Principles on Internal Displacement, delivered to the Economic and Social Council, 2-3, U.N. Doc. E/CN.4/1998/53/Add.2 (Feb. 11, 1998) [hereinafter Principles on Internal Displacement]. See also U.N. High Comm'r for Refugees, The State of the World's Refugees 2006: Human Displacement in the New Millennium 167 (2006) (dealing with IDPs).
} 
term environmental refugee is a misnomer (Ogata, 1992).

\section{Climate Refugee}

Several proposals have been advanced to address the issue of environmental displacement. It is foreseeable that it will be difficult to expand the scope of the 1951 Refugee Convention to cover EDPs, because an expansion would devalue the current protection for refugees; EDPs are not fleeing state persecution and they do not meet the requirement laid down in Article 1 of the Refugee Convention (Keane, 2004). The main difference between as refugee or EDPs is that under international law, EDPs do not enjoy any rights apart from the basic human rights that are accorded to all human beings. They are not eligible to seek for asylum under international law because they are not refugees, ${ }^{14}$ and most importantly, these EDPs remain to be a domestic issue.

While the notion of "environmental refugees" usually includes "climate refugee", critics have argued that this term is too broad to specify or quantify climate-related migration (Biermann \& Boas, 2010). Critics such as Bierman and Boass define climate refugee as "people who have to leave their habitats, immediately or in the near future, because of sudden or gradual alteration in their natural environment related at least to one of the three impacts of climate change: direct impact of climate change to: sea level rise, extreme weather events, and drought and water scarcity. ${ }^{15}$ However, these critics advocates to create a sui generis system outside the currently available legal frame work. They especially argue that the regime of protection should not depend on whether or not the climate refugees have crossed an international border (Biermann \& Boas, 2008).

\section{Disappearing States}

Another grave consequence is the situation of Small Island States, which may become completely submerged as a result of climate change induced sea-level rise (Yamamoto \& Esteban, 2009). For example, Maldives is a country likely to become a disappearing state. There is conflicting information on the timeline for the country's complete immersion, but it is generally understood that major habitability concerns will arise years before the country ceases to physically exist. Hence, Maldives has emerged as a leader in complex engineering projects to battle sea level rise (Fujima et al., 2005). One of Maldives' most significant recent projects was the completion of an artificial island called Hulhumalé within waters under its sovereign control. ${ }^{16}$ Hulhumalé serves to cover future needs on terms of housing, industrial and commercial development. The island also hosts the Malé airport and in contrast to the natural island of Malé stands at $2 \mathrm{~m}$ above sea level, in order to face a possible sea level rise (Tsaltas, Bourtzis, \& Rodotheatos, 2014).

For other Small Island States without mitigation or adaptation strategies, the present population of these countries will become stateless if their territory submerged under water. While international law has dealt with state succession and the resulting legal situation, it has yet to deal with situation where states completely disappear. ${ }^{17}$ There is no framework dealing with citizens with uninhabitable countries. ${ }^{18}$ The international community needs to address the legal vacuum that would arise as a result of states disappearing due to

\footnotetext{
14 Sumudu, supra 3 at 627.

15 Id, Frankat 67.

${ }^{16}$ Id, Fujima et al at 69.

17 See U.N. High Commissioner for Refugees, Climate Change and the Risk of Statelessness: The Situation of Low-lying Island States, 19, U.N. Doc. PPLA/2011/04 (May 2011). See also Susin Park, "Climate Change and the Risk of Statelessness: The Situation of Low-lying Island States", Legal and Protection Policy Research Series, UNHCR (Mary 2011) at 8 (noting that "loss of the entire territory of a state or the exile of the entire population and government is without precedent”).

18 Reed supra 5, at 503.
} 
consequences associated with climate change.

According to The Montevideo Convention signed on December 6, 1933, and lays out the requirements and qualifications of statehood. Article 1 of the Convention states: "The state as a person of international law should possess the following qualifications: a) a permanent population; b) a defined territory; c) government; and d) the capacity to enter into relations with the other states". ${ }^{19}$ International law does not require the territory to be of a particular size (Damrosch, Henkin, \& Murphy, 2001) nor does it require a particular number of people to be present to satisfy the requirement of population. ${ }^{20}$ However, it would seem that territory, however small, is necessary for statehood (Crawford, 2006).

On the other hand, there is a strong presumption against extinction of states once they are firmly established so the disappearance of territory, by itself, may not lead to a loss of sovereignty. ${ }^{21}$ Furthermore, in the Island of Palmas case, a seminal case on acquisition of title to territory before the Permanent Court of Arbitration, the Arbitrator stressed that "sovereignty is the right to exercise in regard to a portion of the globe ... to the exclusion of any other State, the functions of a State". ${ }^{22}$ Thus, by all accounts, territory plays a crucial role in relation to statehood and sovereignty. ${ }^{23}$ Importantly, territory does not mean only physical land. Under the 1982 UN Convention on the Law of the Sea, sovereignty extends to the territorial sea and the air space above that as well as over the exclusive economic zone (EEZ). ${ }^{24}$

\section{Current Legal Framework and Its Insufficiency}

In order to solve the issues regarding to people and states affected by sea level rise, different proposals have been proposed such as to adopting a separate, stand alone convention on climate refugees (Docherty \& Giannini, 2009), or recognizing nation's ex-situ (Burkett, 2011). Instead of proposing for a new legal regime, there are two currently available legal instruments which have the potential to resolve some of the issues raised in this paper. First, the Draft Convention on the International Status of Environmentally-Displaced Persons will be discussed follow by the United Nations Convention on Law of the Sea.

\section{The Draft Convention on the International Status of Environmentally-Displaced Persons}

The Draft Convention on the International Status of Environmentally-Displaced Persons ("Draft Convention” $)^{25}$ proposed by the Interdisciplinary Centre of Research on Environmental, Planning and Urban Law is the most elaborate effort toward such a framework. Its objective is to establish a legal framework that guarantees the rights of EDPs and to organize their reception as well as their eventual return, in application of the principle of solidarity. ${ }^{26}$ The Draft Convention defines "environmentally-displaced persons" as "individuals, families and populations confronted with a sudden or gradual environmental disaster that inexorably impacts their living conditions, resulting in their forced displacement, at the outset or throughout

${ }^{19}$ Convention on the Rights and Duties of States, Dec. 26, 1933, 164 L.N.T.S. 19.

20 Id. at 255 n. 3.

${ }^{21} \mathrm{Id}, 715$.

${ }^{22}$ Island of Palmas Case (Neth./U.S.), 2 RIAA 829, 839 (1928).

23 Sumudusupra 5, at 15.

${ }^{24}$ U.N. Convention on the Law of the Sea, Dec. 10, 1982, 1833 U.N.T.S. 397.

25 The Draft Convention on the International Status of Environmentally-displaced Persons (2010), available at http://www.cidce.org/pdf/Draft\%20Convention\%C20on\%C20the\%20International\%20Status\%20on\%20environm\%20displaced \%20persons\%C20\%C28second\%C20version\%29.pdf.

${ }^{26}$ See Preamble and Article 1 of the Draft Convention. 
from their habitual residence". ${ }^{27}$ A "sudden environmental disaster" is defined as "a rapidly occurring degradation of natural and/or human origin" 28 , while a "gradual environmental disaster" is defined as "a slow, progressive or planned degradation of natural and/or human origin". ${ }^{29}$ It further defines "forced displacement" as "any temporary or permanent displacement made inevitable by environmental disaster, either within a State or from the State of residence to one or more receiving States, of individuals, families or populations". ${ }^{30}$

The difficulty of this Draft Convention is the need of elaborate institutional framework to implement its provisions. Such as the establishment of a national commission on environmental displacement in each signatory state, a High Authority to hear appeals from the national commission, a World Agency for Environmentally-Displaced Persons (WAEP), and a conference of parties. ${ }^{31}$ All of these issues raise the question whether there will be any political support for the adoption of such a convention when the economic and political stakes of ratification seem very high with the potential numbers of such displaced persons. The most troublesome issue is that the framework will not cover those currently living on Small Island States as the Draft Convention envisions the eventual return of these displaced populations to their homes when such return is possible. ${ }^{32}$

\section{United Nations Convention on the Law of the Sea (UNCLOS)}

While it is difficult to expand the refugee status to people affected by climate change. Some countries are seeking self-help to avoid its residents from becoming climate refugee or EDP. Maldives has planned adaptation measures in a long term effort to save itself from extinction (Cameron, 2009). Short term projects include potentially moving all occupants into a few large islands as part of the "Safe Island" project and building up some existing islands to a higher elevation (Lamb, 2005). Creating the "Great Wall of Malé" a concrete wall surrounding the one-square mile capital island of Malé, to mitigate the effects of flooding (Revkin, 2008). Long term plans include buying new lands from India or Sri Lanka ${ }^{33}$. The most significant project so far, Maldives has built an artificial island, Hulhumalé with the potential use as a safe haven against climate change, other states such as Tuvalu is also considering the option (Matau, 2010).

A one-meter rise in the sea level in the coming centuries would mean Maldives, as a state, will total vanish (Secretariat of the United Nations Framework Convention on Climate Change, 2007). If this day do come, could Maldives use artificial islands as a way to preserve its territorial sovereignty over means of the vanishing lands, this is an issue left unanswered by the scientific community and policy makers. Existing laws and policies seem to suggest the opposite, for example, The UNHCR presumes that a state would not cease to exist if its territory is temporarily disappeared (U.N. High Commissioner for Refugees, 2009). Artificial Island are not island under UNCLOS Art. 121(1) which states that "an island is a naturally formed area of land...”, this definition limits the status of artificial island and means that these artificial islands do not have the effect on the generation of maritime zones, ${ }^{34}$ which could have profound economic impact to Maldives as its second largest

\footnotetext{
27 See Article 2.2 of the Draft Convention.

28 See Article 2.2.1 of the Draft Convention.

${ }^{29}$ See Article 2.2.2 of the Draft Convention.

${ }^{30}$ See Article 2.2.3 of the Draft Convention.

31 Sumudu supra 5 at 33.

32 See article 1 of The Draft Convention, “The objective of this Convention is to establish a legal framework that guarantees the rights of environmentally-displaced persons and to organize their reception as well as their eventual return, in application of the principle of solidarity.

${ }^{33} \mathrm{Id}$.

${ }^{34}$ See Art. 60(8) of UNCLOS.
} 
income asides from tourism, is fishery. UNCLOS also has limited definition for artificial island and countries has limited jurisdictions on the artificial island. ${ }^{35}$ In addition, under UNCLOS, artificial island are meant for use on exploration and exploitation resources or other economic activities other than exploration and exploitation of natural resources, this further limits the idea of allowing population to sustain themselves.

\section{Ways Forward}

Climatologists admits that they cannot predict with any certainty what the meteorological effects of climate change will be for many areas. They, however, generally agree that any further global warming will bring with it further sea level rise, and sea level rise is the most globally uniform consequence of warming projected in to the next century (Caron, 1990). As a result many Small Island States will lose one of the basic requirements to be considered as a state: their territory. Unfortunately, the international community has pay too little attention in this area.

The issues can be summarized into three points: first, there is no international consensus on the definition of climate refugee; second, although the Draft Convention recognizes the possibility of people being affected by climate change, the Draft Convention only recognizes them as displaced person and will eventually return to their country of origin; and third, even if the countries at risk are trying to adapt to the consequences due to sea level rise, current international law does not recognize artificial islands to have the possibility of achieving statehood.

The lack of international consensus in this regard is due to the complexity of the issue and the lack of precedent that no state has actually submerged till this date. In addition, there is no scientific basis to show whether submerged territory will be temporary or permanent. Hence, the Draft Convention is based on the fact of eventual return but what if the state has vanished permanently? In regard to Maldives' adaptation effort, maybe it is the time for UNCLOS to expand its definition to allow technological installations to replace the lost territory and eventually to allow that nation to remain its sovereignty. UNCLOS could refine its inadequate definition for artificial islands and set up rules on under what criteria could a country affected by sea level rise to build artificial islands and ways to prevent abuse. By incorporating new rules into the current law, UNCLOS can continue to respond to changes in the international order regarding oceans.

\section{Conclusion}

Sea level rise poses unprecedented challenges to the very core of the international legal order, threatening the foundations of international law. Nation's sovereignty will be threatened as a result of climate change, particularly in relation to Small Island States which are especially vulnerable to these consequences. Despite the lack of international consensus, one thing is clear: people of these states cannot be left to fend for themselves alone simply because there is a legal vacuum. The international community should use this as an opportunity to refine the existing rules in relation to the various challenges posed by climate change. The impact of climate change whether temporal or permanent, will only increase in the future, time is no longer on our side and it is time for the international community to take some substantive actions.

\footnotetext{
${ }^{35}$ See art. 60(2) of UNCLOS (The coastal State shall have exclusive jurisdiction over such artificial Islands, installations and structures, including jurisdiction with regard to customs, fiscal, health, safety and immigration laws and regulations).
} 


\section{References}

Atapattu, S. (2009). Climate change, human rights, and forced migration: Implications for International Law. Retrieved from http://heinonline.org/HOL/LandingPage?handle=hein.journals/wisint27\&div=23\&id=\&page=

Atsapattu, S. (2014). Climate Change: Disappearing States, Migration, and Challenges for International Law. Retrieved from https://digital.lib.washington.edu/dspace-law/bitstream/handle/1773.1/1356/4WJELP1.pdf;sequence=3

Barbour, E. C. (2010). International agreements on climate change: Selected legal questions 1. Retrieved from http://fpc.state.gov/documents/organization/142749.pdf

Biermann, F., \& Boas, I. (2008). Protecting climate refugees: The case for a global protocol (Nov-Dec 2008). Retrieved from http://www.environmentmagazine.org/Archives/Back\%20Issues/November-December\%202008/Biermann-Boas-full.html

Biermann, F., \& Boas, I. (2010). Preparing for a warmer world: Towards a global governance system to protect climate refugees. Global Environmental Politics, 10(1), 60-88.

Burkett, M. (2011). The Nation Ex-Situ: On climate change, deterritorialized nationhood and the post-climate era. Clim Law, 2(3), 345-374.

Cameron, E. (2009). The human dimension of global climate change. 15 HASTINGS W.-Nw. J. ENVrrL. L. \& POL'Y 1, 9-10.

Caron, D. D. (1990). When law makes climate change worse: Rethinking the law of baselines in light of a rising sea level. Ecol Law Q, 17, 621-653.

Crawford, J. (2006). Creation of states in international law. Oxford: Oxford University Press.

Damrosch, L., Henkin, L., \& Murphy, S. (2001). International law: Cases and materials. New York: West Publishing.

Docherty, B., \& Giannini, T. (2009). Confronting a rising tide: A proposal for a convention on climate change refugees. Harvard Environmental Law Review, 33(2), 349-405.

Fujima, K., Tomita, T., Honda, K., Shigihara, Y., Nobuoka, H., Hanzawa, M., ..., Koshimura, S. (2005). Preliminary report on the survey results of 26/12/2004 Indian Ocean Tsunami in the Maldives. Retrieved from http://www.nda.ac.jp/ fujima/maldives-pdf/contents/cover.pdf

Gorlick, B. (n.d.). Environmentally displaced persons: A UNHCR perspective. Retrieved from http://www.ony.unu.edu/seminars/2007/16May2007/Presentation_gor;ick.ppt

Intergovernmental Panel on Climate Change 4th Report, Summary for Policymakers. (2007). Retrieved from www.ipcc.ch/pdf/assessment-report/ar4/syr/ar4_syr_spm.pdf

Jones, N. (2013). Rising Waters: How Fast and How Far Will Sea Levels Rise?. Retrieved from http://e360.yale.edu/feature/rising_waters_how_fast_and_how_far_will_sea_levels_rise/2702/

Keane, D. (2004). The environmental causes and consequences of migration: A search for the meaning of "Environmental Refugees”. Georgetown International Environmental Law Review, 16, 209-223.

Koenig, R. (2015). Climate change's first causalities: Migration and disappearing states. GEO. IMMIGR. L. J. (pp. 501-502).

Lamb, S. (2005). Paradise (Soon to be) Lost. Retrieved from http://www.spiegel.de/international/0,1518,341669,00.html

Matau, R. (2010). Tuvalu, Kiribati look at options to relocating. Retrieved from http://www.pina.com.fj/?p=pacnews\&m=read\&o=7544228754b550cb34f172e1058050\&PHPSESSID=f29620c841a39d6e00 3cb9df38bf4b8f

Ogata, S. (1992). United Nations High Commissioner for Refugees, at the Swiss Peace Foundation, Statement in Geneva. Retrieved from http:// www.unhcr.org/admin/ADMIN/3ae68fad20.html

Rajan, S. C. (2008). Blue Alert - Climate Migrants in South Asia: Estimates and Solutions - A Report by Greenpeace. Retrieved from http://www.greenpeace.at/uploads/media/blue-alert-report_web.pdf

Revkin, A. C. (2008). Maldives considers buying dry land if seas rise. N.Y. Times (Nov.11, A10).

Secretariat of the United Nations Framework Convention on Climate Change. (2007). Vulnerability and adaptation to climate change in Small Island Developing States. Retrieved from http://unfccc.int/files/adaptation/adverse_effects_and_response_measures_art_48/application/pdf/200702_sids_adaptation_b g.pdf

Thead, E. A. (2016). Sea Level Rise: Risk and Resilience in Coastal Cities. Retrieved from http://climate.org/sea-level-rise-risk-and-resilience-in-coastal-cities/

Tsaltas, G., Bourtzis, T., \& Rodotheatos, G. M. (2014). Artificial Islands and structures as a means of safeguarding state Sovereignty against sea level rise: A law of the sea perspective. Retrieved from https://papers.ssrn.com/sol3/papers.cfm?abstract_id=2409890 
U.N. Development Programme, Human Development Report 2007/2008. (2007). Fighting Climate Change: Human Solidarity in a Divided World. Retrieved from http:/hdr.undp.org/en/reports/global/hdr2007-2008.

U.N. High Commissioner for Refugees. (2009). Climate change and statelessness: An overview. Retrieved from http://www.unhcr.org/refworld/docid/4a2d189d3.html

Yamamoto, L., \& Esteban, M. (2009). Vanishing Island and Sovereignty. Ocean and Coastal Management, 53, 1-9. 